\title{
Evaluation of the efficiency of irrigation methods on the growth and survival of tree seedlings in an arid climate
}

\author{
Zahra JAFARI ${ }^{1 *}$, SayedHamid MATINKHAH ${ }^{1}$, Mohammad R MOSADDEGHI ${ }^{2}$, Mostafa \\ TARKESH ${ }^{1}$ \\ ${ }^{1}$ Department of Natural Resources, Isfahan University of Technology, Isfahan 8415683111, Iran; \\ ${ }^{2}$ Department of Soil Science, Department of Agriculture, Isfahan University of Technology, Isfahan 8415683111, Iran
}

\begin{abstract}
Scarce and scattered precipitation in arid regions is detrimental for newly planted seedlings. It is essential to provide required water storage for seedlings in restoration projects in the first year of their establishment. The subsurface irrigation can be much more effective than the surface irrigation because of the regulation of water availability and reduction in water evaporation. We studied the effect of surface and subsurface irrigation methods on the growth and survival of four common tree species including heaven tree (Ailanthus altissima (Mill.) Swingle), China berry (Melia azedarach L.), white mulberry (Morus alba L.), and black locust (Robinia pseudoacacia L.) by installing underground clay reservoirs with different permeabilities in Isfahan City, Iran. Different amounts of animal manure and wheat straw were mixed with clay fraction and cooked in a pottery kiln at $900^{\circ} \mathrm{C}$ to produce reservoirs with different permeabilities. The experimental treatments consisting of irrigation and tree species were considered with a factorial arrangement in a completely randomized design with three replications in 2016 and 2017. Leaf water potential of seedlings, which is indirectly related to drought resistance, was measured by a portable pressure chamber. The results showed that saplings height, basal diameter, number of leaves, chlorophyll content and stomatal conductance were significantly $(P<0.05)$ higher in the subsurface irrigation with low permeability than in the surface irrigation, but the number of branches of the studied species were not significantly $(P>0.05)$ affected by the irrigation methods and different permeabilities of clay reservoirs. The clay reservoirs with low and medium permeabilities constantly provide better conditions for plant growth, and water with lower pressure and longer time intervals to the plant roots as compared with the reservoirs with high permeability. Analysis of variance of the data showed that year and interaction between year and permeability of reservoir had significant effects $(P<0.05)$ on all growth parameters, except for the chlorophyll content. In addition, the highest percentage of survival was $100 \%$ associated with the subsurface irrigation and the control treatment had the lowest survival percentages of $60 \%, 70 \%$, $80 \%$ and $100 \%$ for M. alba, M. azedarach, A. altissima and R. pseudoacacia, respectively. Finally, the values of leaf water potential showed that R. psendoacacia was the most drought resistant species.
\end{abstract}

Keywords: subsurface irrigation; clay reservoirs; permeability; restoration; arid area

Citation: Zahra JAFARI, SayedHamid MATINKHAH, Mohammad R MOSADDEGHI, Mostafa TARKESH. 2020. Evaluation of the efficiency of irrigation methods on the growth and survival of tree seedlings in an arid climate. Journal of Arid Land, 12(3): 495-507. https://doi.org/10.1007/s40333-020-0012-y

\footnotetext{
${ }^{*}$ Corresponding author: Zahra JAFARI (E-mail: jafariz68@yahoo.com)

Received 2019-06-07; revised 2020-04-05; accepted 2020-04-10

(C) Xinjiang Institute of Ecology and Geography, Chinese Academy of Sciences, Science Press and Springer-Verlag GmbH Germany, part of Springer Nature 2020
} 


\section{Introduction}

Water scarcity is the main problem that many societies and the world face in the $21^{\text {st }}$ century (Water, 2007). Water resources are the most strongly limiting factors for the growth of plants, especially in semi-arid and arid regions (Postel, 2000). Therefore, the use of water-efficient irrigation is one of the most practical options to reduce global water scarcity in restoration efforts (Levidow et al., 2014). Availability of water will dictate many decisions regarding the design of an irrigation system for restoration projects. Various irrigation methods, such as surface, subsurface, sprinkler and drip irrigations can be used to irrigate plants and to deal with water deficiency. The method selected depends on physical, economic and social factors, and in turn determines the efficiency of water resources use, economic viability and the sustainability of systems (Gunston and Ali, 2012). Surface irrigation has well-known limitations including the inability to deliver small amounts of water, the occurrence of in-season water losses by deep percolation and surface runoff, and the generally lower distribution uniformity that may cause water stress to plants (Zaccaria et al., 2017). Therefore, it is necessary to adopt appropriate irrigation methods, which supply the optimum quantity of water to the plants.

Subsurface irrigation has been developed since the beginning of human civilization through the use of buried clay pots (Bainbridge, 2001), porous subsurface clay pipes (Ashrafi et al., 2002), subsurface drip irrigation (Camp, 1998) and semi-permeable membranes (Zhang et al., 2012). These systems apply irrigation water directly to the plant under the ground in contrast to the surface irrigation systems, and water losses due to evaporation and surface runoff are minimized in these systems. Bonachela et al. (2001) measured the evaporation from the wet bulb for surface drip-irrigated olive orchards. They estimated that the evaporation represented a fraction of the seasonal orchard evapotranspiration ranging from $4 \%$ to $12 \%$ for a mature orchard and from $18 \%$ to $43 \%$ for a young orchard, depending mainly on the fraction of wetted soil surface. There is a need to adopt irrigation methods that have the higher water use efficiency but with low economic cost, maintenance and supervised operation hours. Siyal et al. (2011) also reported that with the clay pipe irrigation method, water savings up to $80 \%$ were achieved compared with those of surface irrigation methods. Subsurface irrigation systems may provide an improvement in irrigation water use efficiency and could increase the plant yield. Camp (1998) compared the crop yield for both surface and subsurface irrigation methods. He concluded that crop yields for subsurface drip systems were equal to or better than the other systems in all cases, including different crops, soils and cropping conditions. Elhindi et al. (2016) found that subsurface drip irrigation resulted in an increase in the plant height, number of branches, shoot dry weight, root dry weight, flower diameter, flower number and flower dry weight of Zinnia elegans by $2.63 \%$, $1.76 \%, 7.59 \%, 3.26 \%, 0.18 \%, 2.46 \%$ and $0.46 \%$, respectively, when compared with the surface irrigation. These findings may be attributed to the ability of subsurface drip irrigation to maintain optimum soil water content in the root zone (Thompson and Doerge, 1996). Heitzman (1977) found that subsurface irrigation systems were beneficial for trees in arid regions. Al-Amoud (2010) also concluded that subsurface irrigation systems were durable and highly efficient for irrigating date palm trees in arid zones.

Following the lead of those studies carried out on restoration techniques for planting trees in arid lands, the purpose of this study was to evaluate the efficiency of the subsurface irrigation systems using clay reservoirs with different permeabilities versus the surface irrigation on the growth indicators and viability of tree saplings. In addition, the other aim was to select suitable tree species by measuring leaf water potential for restoration efforts. Moreover, the effect of permeability variation of clay reservoirs on the growth and vitality of tree species in the restoration projects was also considered.

\section{Materials and methods}

\subsection{Study area}

The study was conducted at the campus of Isfahan University of Technology $\left(32^{\circ} 43^{\prime} \mathrm{N}, 51^{\circ} 33^{\prime} \mathrm{E}\right.$; 
$1600 \mathrm{~m}$ a.s.1.), northwestern Isfahan City, Iran. The study area is characterized by dry and hot summers and mild and humid winters. The annual mean temperature is $17.0^{\circ} \mathrm{C}$, the mean annual precipitation is $116.9 \mathrm{~mm}$, and the relative humidity is $38 \%$. The hottest and coldest months of the year are reported in July and January, respectively. The maximum and minimum absolute temperatures in the area are $48^{\circ} \mathrm{C}$ and $-30^{\circ} \mathrm{C}$, respectively (Soltani, 2004). The most important threatening factor in the area is severe winds from west, southwest and northwest. The wind speed in the area varies from 6.6 to $11.9 \mathrm{~m} / \mathrm{s}$ during the day and 4.6 to $8.9 \mathrm{~m} / \mathrm{s}$ at night from the west and southwest (Karimi and Mousavi, 1996).

\subsection{Experimental design and treatments}

The experiment was factorial in a completely randomized design with three replications. The experimental treatments consisted of irrigation and tree species. The porous clay reservoirs for subsurface irrigation were made with a height of $50 \mathrm{~cm}$ and an outer diameter of $11 \mathrm{~cm}$ (i.e., a volume of $4749.25 \mathrm{~cm}^{3}$ ) to irrigate the saplings. We used plaster molds to make clay reservoirs, and then these clay reservoirs were cooked in a pottery kiln at $900^{\circ} \mathrm{C}$. The planting pits, 50 $\mathrm{cm} \times 50 \mathrm{~cm}$ (width and depth) with a distance of $2 \mathrm{~m}$, were drilled and the saplings together with clay reservoirs were placed in the pits. A lid was placed on the mouth of each reservoir to avoid evaporation loss. Then, the saplings including four species, i.e., heaven tree (Ailanthus altissima (Mill.) Swingle), China berry (Melia azedarach L.), white mullberry (Morus alba L.) and black locust (Robinia pseudoacacia L.) were planted in March 2016.

The clay reservoirs supplied the water to the saplings through their wall leakage (Fig. 1). All the treatments were under the same environmental conditions. In this research, three permeability treatments for the clay reservoirs were considered and compared with the control (i.e., surface irrigation where water was applied and distributed over the soil surface). Various permeabilities in the clay reservoirs were attained by adding different amounts of wheat straw and manure to the clay reservoirs. The dimensions of the clay reservoirs are presented in Table 1.
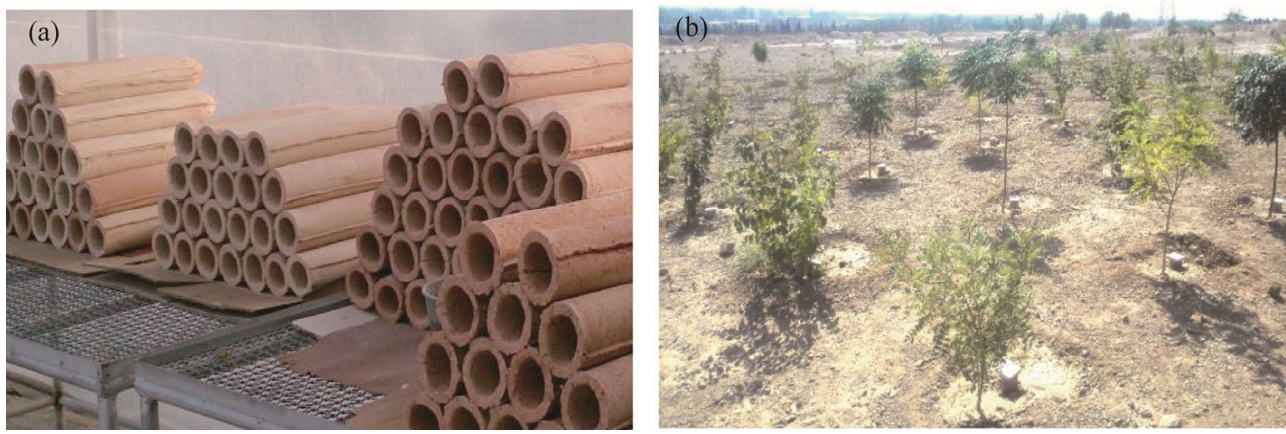

Fig. 1 Clay reservoirs used in this study (a) and view of the project implementation (b)

Table 1 Geometric properties of the clay reservoirs used in this study

\begin{tabular}{cc}
\hline Parameter & Reservoir dimension \\
\hline Thickness $(\mathrm{cm})$ & 1.00 \\
Height $(\mathrm{cm})$ & 50.00 \\
Inner diameter $(\mathrm{cm})$ & 10.00 \\
Outer diameter $(\mathrm{cm})$ & 11.00 \\
Area $\left(\mathrm{cm}^{2}\right)$ & 1916.97 \\
Volume $\left(\mathrm{cm}^{3}\right)$ & 4749.25 \\
\hline
\end{tabular}

\subsection{Irrigation water analysis}

The electric conductivity (EC) and $\mathrm{pH}$ of the irrigation water were measured by an EC-meter and a $\mathrm{pH}$-meter, respectively. Chloride and sodium concentrations were measured by argentometric 
titration and flame-photometer, respectively (Richards, 1954). The carbonate and bicarbonate levels were measured by titration methods. The calcium and magnesium concentrations were calculated by complexometric titration with EDTA (ethylenediamine tetraacetic acid) in the presence of metallo-chromic indicators including Calcon or Murexide for calcium and Eriochrome Black $\mathrm{T}$ for total hardness $\left(\mathrm{Ca}^{2+}+\mathrm{Mg}^{2+}\right)$, where magnesium concentration is obtained by the difference between them (Raij, 1966). The sodium adsorption ratio (SAR) was calculated by Equation 1 (Richards, 1954). The chemical properties of the irrigation water are presented in Table 2.

$$
\mathrm{SAR}=\mathrm{Na}^{+} / \sqrt{\frac{\mathrm{Ca}^{2+}+\mathrm{Mg}^{2+}}{2}} .
$$

Table 2 Chemical properties of the irrigation water

\begin{tabular}{cccccccc}
\hline $\begin{array}{c}\mathrm{EC} \\
(\mathrm{dS} / \mathrm{m})\end{array}$ & $\mathrm{pH}$ & $\begin{array}{c}\mathrm{CO}_{3}^{-} \\
(\mathrm{mmol} / \mathrm{L})\end{array}$ & $\begin{array}{c}\mathrm{HCO}_{3}^{-} \\
(\mathrm{mmol} / \mathrm{L})\end{array}$ & $\begin{array}{c}\mathrm{Cl}^{-} \\
(\mathrm{mmol} / \mathrm{L})\end{array}$ & $\begin{array}{c}\mathrm{Na}^{+} \\
(\mathrm{mmol} / \mathrm{L})\end{array}$ & $\begin{array}{c}\mathrm{Mg}^{2+}+\mathrm{Ca}^{2+} \\
(\mathrm{mmol} / \mathrm{L})\end{array}$ & $\mathrm{SAR}^{2}$ \\
\hline 0.29 & 8.04 & 2.00 & 6.00 & 13.00 & 1.57 & 2.40 & 1.44 \\
\hline
\end{tabular}

Note: EC, electrical conductivity; SAR, sodium adsorption ratio.

\subsection{Soil analysis}

Soil samples were collected from the $0-50 \mathrm{~cm}$ layer below the surface to measure chemical and physical properties. The soil EC and $\mathrm{pH}$ were determined in the saturated extract (Slavich and Petterson, 1993). Soil texture was measured by hydrometer method and soil texture class was determined using the USDA (United States Department of Agriculture) soil texture triangle (Bouyoucos, 1962). Bulk density was determined by core method (Grossman and Reinsch, 2002), and porosity $(f)$ of soil samples was calculated by bulk density and particle density (i.e., 2.65 $\mathrm{Mg} / \mathrm{m}^{3}$ ). Field capacity (FC) and permanent wilting point (PWP) were determined using a pressure plate at matric potentials of -33 and $-1500 \mathrm{kPa}$, respectively (Klute, 1986). Physical and chemical properties of the studied soil are presented in Table 3.

Table 3 Soil physical and chemical properties

\begin{tabular}{cccccccccc}
\hline $\begin{array}{c}\text { Depth } \\
(\mathrm{cm})\end{array}$ & $\mathrm{pH}$ & $\begin{array}{c}\mathrm{EC} \\
(\mathrm{dS} / \mathrm{m})\end{array}$ & $\begin{array}{c}\text { Sand } \\
(\mathrm{kg} / 100 \mathrm{~kg})\end{array}$ & $\begin{array}{c}\text { Clay } \\
(\mathrm{kg} / 100 \mathrm{~kg})\end{array}$ & $\begin{array}{c}\text { Silt } \\
(\mathrm{kg} / 100 \mathrm{~kg})\end{array}$ & $\begin{array}{c}\mathrm{FC} \\
(\mathrm{kg} / 100 \mathrm{~kg})\end{array}$ & $\begin{array}{c}\mathrm{PWP} \\
(\mathrm{kg} / 100 \mathrm{~kg})\end{array}$ & $\begin{array}{c}\text { BD } \\
\left(\mathrm{Mg} / \mathrm{m}^{3}\right)\end{array}$ & $\begin{array}{c}\text { Porosity } \\
\left(\mathrm{m}^{3} / 100 \mathrm{~m}^{3}\right)\end{array}$ \\
\hline $0-50$ & 8.81 & 2.00 & 48.70 & 21.80 & 29.50 & 13.50 & 8.40 & 1.36 & 51.00 \\
\hline
\end{tabular}

Note: EC, electrical conductivity; FC, field capacity; PWP, permanent wilting point; BD, bulk density.

\subsection{Determination of water depletion from the clay reservoirs}

The percentage of water loss through the reservoir walls was studied by filling the clay reservoir installed in the soil with water up to its neck level. After a specific time, the reservoir was filled with the same water up to the same level to replenish the water loss. The percentage of water release per unit of time was calculated by Equation 2 (Naik et al., 2008):

$$
P=v / V t \times 100 \% \text {, }
$$

where $P$ is the percentage of water loss per unit of time through the reservoir (\%); $v$ is the neck level capacity of the reservoir $\left(\mathrm{cm}^{3}\right) ; V$ is the volume of water required to fill up the reservoir again to its neck level between two consecutive fillings $\left(\mathrm{cm}^{3}\right)$; and $t$ is the time elapsed between two consecutive fillings (h). The time $t$ elapsed between two consecutive fillings was $24 \mathrm{~h}$ for all reservoirs.

\subsection{Plant growth indicators}

In this study, plant growth indicators were recorded during the growth season at monthly intervals for two years (2016 and 2017). The plant height, i.e., the distance between the base and the top of a standing tree (Hucsh et al., 2003), was measured using a meter stick. The plant basal diameter, i.e., stem diameter on the ground surface, was measured using a caliper (Tallant and Pelkki, 2004). The stomatal conductance $\left(\mathrm{mmol} /\left(\mathrm{m}^{2} \cdot \mathrm{s}\right)\right)$ was measured using a hand-held porometer (Pask et al., 2012) and chlorophyll content of plants was measured using the Chlorophyll Content Meter 
CL-01 (Hansatech, Kings Lynn, UK) (Chang and Robison, 2003; Pagola et al., 2009; Hu et al., 2014). In addition, the numbers of branches and leaves per each plant were counted.

\subsection{Percentage of sapling survival}

The viability of plants was evaluated after planting for nine months and reported as the saplings survival percentage in each treatment (Azizi et al., 2015):

$$
\mathrm{SP}=S / n \times 100 \% \text {, }
$$

where SP is the percentage sapling survival (\%); $s$ is the number of remaining saplings at the end of the experiment (a period of nine months); and $n$ is the number of saplings at the start of the experiment in each treatment.

\subsection{Leaf water potential $\left(\Psi_{\mathrm{w}}\right)$}

$\Psi_{\mathrm{w}}$ is a physiological indicator that can be used to identify drought resistance in various species being considered for forestation projects in arid lands. Measurements of $\Psi_{\mathrm{w}}$ were taken using a portable pressure chamber (Model DIK-7000, Daiki Rika Kogyo, Ltd., Tokyo, Japan). A mature leaf with the complete petiole was cut carefully from the saplings using a razor blade. After removal, the leaf was immediately fixed with a rubber stopper in the specimen holder. The entire system was placed in the pressure chamber so that the petiole sap could be clearly observed using a magnifying glass. The $\mathrm{N}_{2}$ gas pressure in the chamber was then gently increased until the sap began flowing from the cut end of the petiole. Finally, the equilibrium pressure $\left(P_{0}\right)$ of the leaf sample was read on the gauge and the $\Psi_{\mathrm{w}}$ was considered equal to $P_{0}$ with a negative sign (i.e., $\left.\Psi_{\mathrm{w}}=-P_{0}\right)($ Kirkham, 2014).

\subsection{Statistical analysis}

The normality of the data was controlled by a Kolmogorov-Smirnov test and homogeneity of variances with a Leven's test. Significant effects of the treatments were tested by a two-way ANOVA (analysis of variance) with repeated observations during two years, followed by LSD (least significant difference) test at $P<0.05$ and $P<0.01$ levels by using SAS 9.4 software. The results are expressed as the mean $\pm \mathrm{SE}$ of three observations for each treatment.

\section{Results and discussion}

\subsection{Water depletion from the clay reservoirs}

The water depletion percentage of the clay reservoirs with different permeabilities is shown in Table 4. We defined three treatments, namely, reservoirs with low, medium and high permeability in this study according to the water depletion percentage of the clay reservoirs. At high cooking temperature, organic materials were completely burned and different pore spaces were produced in their places, which resulted in different permeabilities of the reservoirs with respect to the quantity of organic matter. Moreover, it was expected that organic materials had minimal nutritional and direct influences on the survival and growth of seedlings.

Water depletion of the clay reservoirs with time is shown in Figure 2. The water depletion percentage of the clay reservoirs was initially high in all treatments, but gradually increased over the time, due to the fact that the clay reservoirs walls were saturated in the early stages of the

Table 4 Water depletion percentage of the clay reservoirs with different permeabilities after $24 \mathrm{~h}$

\begin{tabular}{cccc}
\hline Clay reservoir type & Materials used for preparation & Percentage of water depletion after 24 h (\%) & Permeability \\
\hline $\mathrm{R}_{1}$ & $95 \%$ clay $+5 \%$ manure & 0.22 & Low \\
$\mathrm{R}_{2}$ & $95 \%$ clay $+5 \%$ wheat straw & 0.24 & Medium \\
$\mathrm{R}_{3}$ & $100 \%$ clay soil & 0.30 & 0.48 \\
$\mathrm{R}_{4}$ & $60 \%$ clay $+40 \%$ manure & 0.50 & High \\
$\mathrm{R}_{5}$ & $60 \%$ clay $+40 \%$ wheat straw & & \\
\hline
\end{tabular}




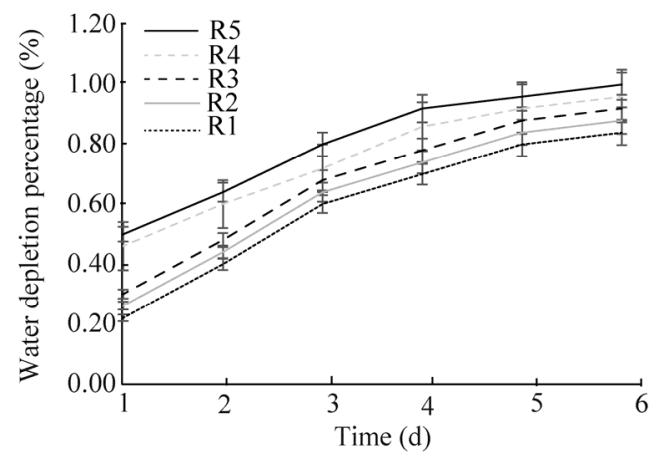

Fig. 2 Water depletion percentage of the clay reservoirs with different permeabilities with time. The clay reservoir types of R1-R5 are explained in Table 4.

experiments and the water height lowering in the reservoirs would reduce the saturated part off the lateral walls through which the water flow occurred. Indeed, the water head in the reservoir as a component of the driving force for the water flow would increase with the time. Then, the depletion of water showed a steady trend by balancing the water in the pottery reservoirs during the time. Bhatt et al. (2008) found that the rate of water depletion through the pitchers was a result of the water requirements of plant. It is evident that $R_{1}$ and $R_{2}$ showed the lowest percentages of water depletion, and then, $R_{3}$ and finally $R_{4}$ and $R_{5}$ showed the highest percentages of water depletion (Fig. 2). The use of certain quantities of wheat straw and manure substantially affected the water depletion. Plants with a high evapotranspiration demand can be suitably irrigated with $\mathrm{R}_{4}$ and $\mathrm{R}_{5}$ clay reservoirs because of their high depletion rates. Plants with a low evapotranspiration demand can be suitably irrigated with the conventional reservoirs made of clay, and low percentages of manure and wheat straw (i.e., $\mathrm{R}_{1}$ and $\mathrm{R}_{2}$ ) due to their low depletion rates. It seems that the use of high percentages of manure and wheat straw might induce the formation of pores and microcracks (i.e., increased porosity) in the walls of reservoirs, and therefore, result in a higher water depletion rate.

\subsection{Plant growth indicators}

Results of the growth indicators of tree saplings under different treatments during two years are shown in Tables 5 and 6.

As shown in Table 5, the reservoir's permeability had a significant effect $(P<0.05)$ on all the growth indicators, except the number of branches of $A$. altissima. The year had a significant effect $(P<0.05)$ on all growth indicators, except the chlorophyll content of $A$. altissima. The height, diameter number of branches and number of leaves increase as plant grows. Stomatal conductance also increases. Chlorophyll content is affected by light density, not by plant growth. Chlorophyll content can act as an index for age/nutrient status of the leaves. Data show that the interaction between reservoir's permeability and year on the plant height, basal diameter, number of leaves and stomatal conductance was statistically significant $(P<0.05)$.

The reservoir's permeability had a significant effect $(P<0.05)$ on all the growth indicators, except the number of branches of $M$. azadirachta, $M$. alba and $R$. pseudoacacia. The year had a significant effect $(P<0.05)$ on all growth indicators, except the chlorophyll contents of $M$. azadirachta, $M$. alba and $R$. pseudoacacia. Data show that the interaction between the reservoir's permeability and year on the plant height, basal diameter, number of leaves and stomatal conductance was statistically significant $(P<0.05)$.

\subsubsection{Plant height}

The means comparisons of the plant's height between the surface and subsurface irrigation methods (Table 6) indicate that the subsurface irrigation system significantly increased the plants height. Douh and Boujelben (2010) confirmed that the irrigation system has a highly significant effect on the plants height growth and the highest plant heights were recorded in the case of the subsurface drip irrigation through comparing the plants' heights between the surface and subsurface irrigation methods. The results show that the averages of plant height were 45 and 55 
Table 5 Analysis of variance of the growth indicators of plant species under different treatments

\begin{tabular}{|c|c|c|c|c|c|c|c|c|}
\hline \multirow[b]{2}{*}{ Species } & \multirow[b]{2}{*}{ Source of variation } & \multirow[b]{2}{*}{$d f$} & \multicolumn{6}{|c|}{ Mean square } \\
\hline & & & Height & $\begin{array}{c}\text { Basal } \\
\text { diameter }\end{array}$ & $\begin{array}{c}\text { Number of } \\
\text { branches }\end{array}$ & $\begin{array}{l}\text { Number of } \\
\text { leaves }\end{array}$ & $\begin{array}{c}\text { Chlorophyll } \\
\text { content }\end{array}$ & $\begin{array}{c}\text { Stomatal } \\
\text { conductance }\end{array}$ \\
\hline \multirow[t]{7}{*}{ A. altissima } & Permeability & 3 & $1070.83^{*}$ & $26.06^{*}$ & $0.15^{\mathrm{ns}}$ & $135.15^{*}$ & $69.59^{*}$ & $906.80^{*}$ \\
\hline & $\begin{array}{c}\text { Replication } \\
\text { (Permeability) }\end{array}$ & 8 & $191.66^{\mathrm{ns}}$ & $7.86^{*}$ & $0.12^{\text {ns }}$ & $2.25^{\mathrm{ns}}$ & $11.66^{\mathrm{ns}}$ & $9.09^{\text {ns }}$ \\
\hline & Year & 1 & $4537.50^{*}$ & $270.68^{*}$ & $22.04^{*}$ & $1365.04^{*}$ & $44.17^{\mathrm{ns}}$ & $181.50^{*}$ \\
\hline & Permeability $\times$ Year & 3 & $2181.94^{*}$ & $104.17^{*}$ & $0.70^{\mathrm{ns}}$ & $3.15^{*}$ & $199.69^{\mathrm{ns}}$ & $5.91^{*}$ \\
\hline & Error & 8 & 133.33 & 2.13 & 0.29 & 4.50 & 14.10 & 20.54 \\
\hline & $R^{2}$ & - & 0.93 & 0.97 & 0.91 & 0.98 & 0.86 & 0.94 \\
\hline & $\mathrm{CV}$ & - & 10.78 & 5.91 & 21.96 & 7.63 & 17.00 & 15.11 \\
\hline \multirow[t]{7}{*}{ M. azadirachta } & Permeability & 3 & $1310.50^{*}$ & $123.56^{*}$ & $0.37^{\mathrm{ns}}$ & $11,929.15^{*}$ & $661.19^{*}$ & $2512.60^{*}$ \\
\hline & $\begin{array}{c}\text { Replication } \\
\text { (Permeability) }\end{array}$ & 8 & $41.79^{\mathrm{ns}}$ & $3.42^{\mathrm{ns}}$ & $0.37^{\mathrm{ns}}$ & $318.70^{*}$ & $33.75^{\mathrm{ns}}$ & $54.56^{\mathrm{ns}}$ \\
\hline & Year & 1 & $7848.16^{*}$ & $1757.53^{*}$ & $3.37^{*}$ & $1998.37^{*}$ & $287.38^{\mathrm{ns}}$ & $490.51^{*}$ \\
\hline & Permeability $\times$ Year & 3 & $1097.16^{*}$ & $111.94^{*}$ & $1.04^{\mathrm{ns}}$ & $84.37^{*}$ & $788.71^{\mathrm{ns}}$ & $25.73^{*}$ \\
\hline & Error & 8 & 24.29 & 1.80 & 0.37 & 33.12 & 67.48 & 47.57 \\
\hline & $R^{2}$ & - & 0.98 & 0.99 & 0.77 & 0.99 & 0.90 & 0.95 \\
\hline & $\mathrm{CV}$ & - & 3.56 & 4.47 & 18.14 & 2.77 & 20.60 & 16.77 \\
\hline \multirow[t]{7}{*}{ M. alba } & Permeability & 3 & $1393.04^{*}$ & $41.08^{*}$ & $11.93^{\mathrm{ns}}$ & $21,643.15^{*}$ & $244.58^{*}$ & $1041.38^{*}$ \\
\hline & $\begin{array}{c}\text { Replication } \\
\text { (Permeability) }\end{array}$ & 8 & $62.91^{\mathrm{ns}}$ & $3.23^{\mathrm{ns}}$ & $1.08^{\mathrm{ns}}$ & $770.75^{*}$ & $60.57^{\mathrm{ns}}$ & $10.78^{\mathrm{ns}}$ \\
\hline & Year & 1 & $187.04^{*}$ & $244.60^{*}$ & $12.04^{*}$ & $2147.04^{*}$ & $565.60^{\text {ns }}$ & $1.38^{*}$ \\
\hline & Permeability $\times$ Year & 3 & $278.04^{*}$ & $32.52^{*}$ & $0.37^{\mathrm{ns}}$ & $16.15^{*}$ & $226.85^{\mathrm{ns}}$ & $28.21^{*}$ \\
\hline & Error & 8 & 47.91 & 1.19 & 0.41 & 113.50 & 66.58 & 5.64 \\
\hline & $R^{2}$ & - & 0.93 & 0.98 & 0.94 & 0.98 & 0.82 & 0.98 \\
\hline & $\mathrm{CV}$ & - & 5.80 & 4.89 & 4.38 & 3.91 & 46.68 & 7.85 \\
\hline \multirow[t]{7}{*}{ R. pseudoacacia } & Permeability & 3 & $2861.77^{*}$ & $184.93^{*}$ & $25.37^{\mathrm{ns}}$ & $2761.48^{*}$ & $81.90^{*}$ & $983.84^{*}$ \\
\hline & $\begin{array}{l}\text { Replication } \\
\text { (Permeability) }\end{array}$ & 8 & $334.00^{\mathrm{ns}}$ & $33.54^{\mathrm{ns}}$ & $6.66^{\mathrm{ns}}$ & $63.83^{\mathrm{ns}}$ & $11.76^{\mathrm{ns}}$ & $26.53^{\mathrm{ns}}$ \\
\hline & Year & 1 & $3174.00^{*}$ & $96.12^{*}$ & $18.37^{*}$ & $1426.04^{*}$ & $0.46^{\mathrm{ns}}$ & $1323.13^{*}$ \\
\hline & Permeability $\times$ Year & 3 & $1251.77^{*}$ & $253.37^{*}$ & $2.37^{\mathrm{ns}}$ & $90.26^{*}$ & $29.94^{\mathrm{ns}}$ & $28.23^{*}$ \\
\hline & Error & 8 & 332.33 & 1.58 & 4.00 & 118.33 & 13.51 & 13.06 \\
\hline & $R^{2}$ & - & 0.87 & 0.97 & 0.82 & 0.91 & 0.79 & 0.97 \\
\hline & $\mathrm{CV}$ & - & 15.10 & 6.50 & 24.87 & 23.71 & 30.95 & 11.32 \\
\hline
\end{tabular}

Note: ${ }^{*}$ means significant effects at $P<0.05$ level. ${ }^{\text {ns }}$, insignificance; $R^{2}$, coefficient of determination; $\mathrm{CV}$, coefficient of variance. - means no value.

$\mathrm{cm}$ in the surface and subsurface drip irrigation systems, respectively. Subsurface irrigation systems are capable of applying small amounts of water directly to the plant root zone where water is needed and can be applied frequently to maintain favorable moisture conditions in the root zone. Subsurface irrigation offers many advantages over surface drip irrigation such as reduced evaporation loss, precise water placement, better management of water, nutrients and pesticides leading to more efficient water use, greater water application uniformity and an enhanced plant growth. Therefore, we also observed that the height of plants increased under subsurface irrigation compared with surface irrigation.

\subsubsection{Plant basal diameter}

Plant basal diameter in the subsurface irrigation system was higher than that in the surface irrigation and this effect was significant (Table 6). Water deficiency at different growth stages in the surface irrigation decreased the basal diameter of plants. However, the subsurface irrigation 
helps to manage water stress, and water is constantly delivered to the plant root. Pandy et al. (2000) demonstrated that drought reduces the stem diameter and plant height through applying water stress at different growth stages of corn. The subsurface irrigation appears to be the best method for supplying uniform soil moisture in the root zone throughout the growing season. One of the first signs of water shortage is the decrease in plant cell turgor which causes a decrease in both growth and cell development, especially in the stem and leaves (Ekren et al., 2012).

\subsubsection{Number of branches}

Number of branches in the subsurface irrigation system was higher than that in the surface irrigation, although this effect was not significant (Table 6). Accordingly, Moghbeli Moheni Dorodi et al. (2016) studied the vegetative and reproductive characteristics of Rosa damascena in different regimes of the surface irrigation and subsurface irrigation and concluded that the numbers of branches per plant were not significantly different in the two irrigation systems. Abubaker et al. (2014) found that the number and fresh weight of stems were not significantly affected by different amounts of irrigation water in the first season, but the effect was significant in the second season. Sanches et al. (2017) found that the number of branches was not affected by different irrigation frequencies. Plants grown at a high nutrient supply or soil moisture content produced more lateral branches (Zhang, 1996). In accordance with our findings, Islam et al. (1990) reported the significant effects of irrigation water quantities on the number of stems of the potato plant.

\subsubsection{Number of leaves}

Number of leaves was higher in the subsurface irrigation than in the surface irrigation (Table 6). Ansari et al. (2014) compared the growth indices of the dominant species of urban green spaces in the jar subsurface, drip and surface irrigation systems and concluded that the average number of leaves per branch in the jar irrigation method is greater than those of in the drip and surface irrigation systems. This finding could be due to the high evaporation of water from the soil surface and the lack of water supply to plants, which is in the line with our results. Accordingly, Rao et al. (2019) reported that the number of leaves and neck or stem thickness was greater in the drip irrigation and the lowest values were recorded in flood irrigation.

\subsubsection{Relative chlorophyll content}

Chlorophyll content is the best indicator of photosynthesis activity, water deficiency, measure of the crop response to nitrogen application, and many other plant biochemical aspects. Variations in pigment content may provide valuable information about the physiological status of plants (Sims and Gamon, 2002). The irrigation method significantly influenced the relative chlorophyll content of plants in this study (Table 6). Therefore, the highest relative chlorophyll content was observed in the subsurface irrigation rather than in the surface irrigation. El-Shikha (2008) observed that chlorophyll content in potato leaves was affected by the irrigation system and the amount of irrigation water. Elhindi et al. (2016) found that the subsurface drip irrigation significantly increased nitrogen availability and other nutrients, enhanced nutrients' uptake, and increased the total chlorophyll content in leaves.

\subsubsection{Stomatal conductance}

Stomatal conductance was significantly higher in the subsurface irrigation than in the surface irrigation (Table 6). These findings support the fact that under water deficiency, the stomata are partially or completely closed. This induces a reduction in $\mathrm{CO}_{2}$ uptake and subsequently the plants expend a huge amount of energy to take up water from the soil, which negatively impacts photosynthetic activities, and consequently reduces the productivity of plants. These findings indicate that the subsurface drip irrigation may increase the availability of water in the root zone, leading to improvements in the plant's water status and better stomatal conductance, which eventually is reflected in its photo-assimilate production (Nielsen and Nelson, 1998).

Generally, observed data showed that the subsurface irrigation system increased sapling growth indicators of A. altissima, M. azedarach, M. alba and R. pseudoacacia when compared with the surface irrigation system (Table 6). The reservoirs with low-permeability result in an increase in 
Table 6 Means' comparisons of growth indictors of plant species under different treatments

\begin{tabular}{|c|c|c|c|c|c|c|}
\hline \multirow{2}{*}{ Year } & \multirow{2}{*}{ Species } & \multirow{2}{*}{ Growth indicator } & \multicolumn{4}{|c|}{ Reservoir's permeability treatment } \\
\hline & & & Low & Medium & High & Control \\
\hline \multirow[t]{24}{*}{2016} & A. altissima & Height $(\mathrm{cm})$ & $115.0 \pm 0.01^{\mathrm{a}}$ & $105.3 \pm 5.77^{\mathrm{a}}$ & $90.7 \pm 15.27^{\mathrm{b}}$ & $80.3 \pm 25.10^{b}$ \\
\hline & & Basal diameter $(\mathrm{cm})$ & $24.5 \pm 1.5^{\mathrm{a}}$ & $22.9 \pm 0.8^{\mathrm{a}}$ & $20.6 \pm 3.9^{\mathrm{a}}$ & $15.0 \pm 3.6^{\mathrm{b}}$ \\
\hline & & No. of branches & $2 \pm 0.5^{\mathrm{a}}$ & $2 \pm 0.9^{\mathrm{a}}$ & $2 \pm 1.0^{\mathrm{a}}$ & $2 \pm 1.0^{\mathrm{a}}$ \\
\hline & & No. of leaves & $26 \pm 1.5^{\mathrm{a}}$ & $24 \pm 3.2^{\mathrm{a}}$ & $19 \pm 3.1^{b}$ & $16 \pm 5.1^{\mathrm{c}}$ \\
\hline & & Relative chlorophyll content & $27.69 \pm 5.1^{\mathrm{a}}$ & $25.39 \pm 3.8^{\mathrm{a}}$ & $20.44 \pm 7.1^{\mathrm{b}}$ & $17.40 \pm 2.1^{\mathrm{c}}$ \\
\hline & & Stomatal conductance $\left(\mathrm{mmol} /\left(\mathrm{m}^{2} \cdot \mathrm{s}\right)\right)$ & $40.86 \pm 3.3^{\mathrm{a}}$ & $37.47 \pm 1.5^{\mathrm{a}}$ & $29.36 \pm 5.9^{b}$ & $23.26 \pm 4.6^{c}$ \\
\hline & M. azedarach & Height $(\mathrm{cm})$ & $143.3 \pm 0.10^{\mathrm{a}}$ & $133.3 \pm 2.80^{\mathrm{a}}$ & $110.0 \pm 5.80^{\mathrm{b}}$ & $103.3 \pm 5.70^{\mathrm{b}}$ \\
\hline & & Basal diameter $(\mathrm{cm})$ & $23.5 \pm 0.2^{\mathrm{a}}$ & $22.7 \pm 2.5^{\mathrm{a}}$ & $19.6 \pm 0.2^{\mathrm{a}}$ & $19.4 \pm 0.1^{\mathrm{a}}$ \\
\hline & & No. of branches & $3 \pm 2.0^{\mathrm{a}}$ & $3 \pm 1.2^{\mathrm{a}}$ & $3 \pm 3.0^{\mathrm{a}}$ & $3 \pm 1.0^{\mathrm{a}}$ \\
\hline & & No. of leaves & $234 \pm 1.0^{\mathrm{a}}$ & $218 \pm 1.5^{\mathrm{a}}$ & $195 \pm 4.9^{b}$ & $168 \pm 6.2^{\mathrm{c}}$ \\
\hline & & Chlorophyll content & $60.15 \pm 5.0^{\mathrm{a}}$ & $57.67 \pm 3.9^{\mathrm{a}}$ & $45.95 \pm 7.2^{\mathrm{b}}$ & $40.82 \pm 2.0^{\mathrm{c}}$ \\
\hline & & Stomatal conductance $\left(\mathrm{mmol} /\left(\mathrm{m}^{2} \cdot \mathrm{s}\right)\right)$ & $60.96 \pm 3.0^{\mathrm{a}}$ & $55.90 \pm 6.9^{\mathrm{a}}$ & $47.46 \pm 1.8^{\mathrm{b}}$ & $39.93 \pm 1.9^{c}$ \\
\hline & M. alba & Height $(\mathrm{cm})$ & $130.0 \pm 0.01^{\mathrm{a}}$ & $123.6 \pm 6.01^{\mathrm{a}}$ & $110.0 \pm 8.00^{\mathrm{b}}$ & $101.6 \pm 2.88^{b}$ \\
\hline & & Basal diameter & $23.0 \pm 2.0^{\mathrm{a}}$ & $20.6 \pm 1.2^{\mathrm{a}}$ & $20.0 \pm 1.3^{\mathrm{a}}$ & $17.3 \pm 0.2^{\mathrm{b}}$ \\
\hline & & No. of branches & $14 \pm 3.0^{\mathrm{a}}$ & $14 \pm 3.0^{\mathrm{a}}$ & $13 \pm 3.0^{\mathrm{a}}$ & $13 \pm 3.0^{\mathrm{a}}$ \\
\hline & & No. of leaves & $232 \pm 7.8^{\mathrm{a}}$ & $328 \pm 3.0^{\mathrm{a}}$ & $288 \pm 10.0^{b}$ & $250 \pm 9.0^{\mathrm{c}}$ \\
\hline & & Relative chlorophyll content & $39.47 \pm 7.3^{\mathrm{a}}$ & $36.10 \pm 3.0^{\mathrm{a}}$ & $27.16 \pm 2.1^{\mathrm{b}}$ & $25.13 \pm 2.3^{b}$ \\
\hline & & Stomatal conductance $\left(\mathrm{mmol} /\left(\mathrm{m}^{2} \cdot \mathrm{s}\right)\right)$ & $44.70 \pm 2.5^{\mathrm{a}}$ & $42.20 \pm 1.4^{\mathrm{a}}$ & $36.60 \pm 2.7^{\mathrm{b}}$ & $30.50 \pm 2.1^{\mathrm{c}}$ \\
\hline & R. pseudoacacia & Height $(\mathrm{cm})$ & $130.0 \pm 5.70^{\mathrm{a}}$ & $126.5 \pm 3.00^{\mathrm{a}}$ & $113.3 \pm 0.50^{\mathrm{b}}$ & $96.6 \pm 5.80^{\mathrm{c}}$ \\
\hline & & Basal diameter $(\mathrm{cm})$ & $19.4 \pm 0.4^{\mathrm{a}}$ & $19.3 \pm 2.0^{\mathrm{a}}$ & $18.3 \pm 0.8^{\mathrm{a}}$ & $14.3 \pm 0.0^{\mathrm{b}}$ \\
\hline & & No. of branches & $6 \pm 3.0^{\mathrm{a}}$ & $6 \pm 3.0^{\mathrm{a}}$ & $6 \pm 3.0^{\mathrm{a}}$ & $6 \pm 3.0^{\mathrm{a}}$ \\
\hline & & No. of leaves & $59 \pm 3.0^{\mathrm{a}}$ & $50 \pm 1.0^{\mathrm{a}}$ & $40 \pm 3.1^{\mathrm{b}}$ & $32 \pm 2.0^{\mathrm{c}}$ \\
\hline & & Relative chlorophyll content & $18.19 \pm 2.5^{\mathrm{a}}$ & $17.77 \pm 1.4^{\mathrm{a}}$ & $12.95 \pm 7.6^{\mathrm{b}}$ & $12.02 \pm 5.7^{\mathrm{a}}$ \\
\hline & & Stomatal conductance $\left(\mathrm{mmol} /\left(\mathrm{m}^{2} \cdot \mathrm{s}\right)\right)$ & $28.60 \pm 3.5^{\mathrm{a}}$ & $28.60 \pm 2.0^{\mathrm{a}}$ & $21.23 \pm 3.6^{\mathrm{b}}$ & $21.00 \pm 1.3^{\mathrm{b}}$ \\
\hline \multirow[t]{24}{*}{2017} & A. altissima & Height $(\mathrm{cm})$ & $146.6 \pm 5.77^{\mathrm{a}}$ & $137.3 \pm 5.01^{\mathrm{a}}$ & $113.3 \pm 3.01^{\mathrm{b}}$ & $90.0 \pm 5.10^{\mathrm{c}}$ \\
\hline & & Basal diameter $(\mathrm{cm})$ & $35.1 \pm 2.2^{\mathrm{a}}$ & $30.1 \pm 2.9^{\mathrm{a}}$ & $26.64 \pm 1.1^{\mathrm{a}}$ & $17.6 \pm 3.1^{\mathrm{b}}$ \\
\hline & & No. of branches & $5 \pm 3.0^{\mathrm{a}}$ & $5 \pm 3.0^{\mathrm{a}}$ & $5 \pm 3.0^{\mathrm{a}}$ & $5 \pm 3.0^{\mathrm{a}}$ \\
\hline & & No. of leaves & $40 \pm 1.2^{\mathrm{a}}$ & $37 \pm 1.0^{\mathrm{a}}$ & $31 \pm 3.6^{\mathrm{b}}$ & $29 \pm 1.5^{b}$ \\
\hline & & Chlorophyll content & $29.20 \pm 0.0^{\mathrm{a}}$ & $27.31 \pm 3.1^{\mathrm{a}}$ & $22.19 \pm 1.6^{\mathrm{b}}$ & $19.26 \pm 1.0^{\mathrm{c}}$ \\
\hline & & Stomatal conductance $\left(\mathrm{mmol} /\left(\mathrm{m}^{2} \cdot \mathrm{s}\right)\right)$ & $41.26 \pm 6.0^{\mathrm{a}}$ & $37.46 \pm 4.5^{\mathrm{a}}$ & $30.86 \pm 6.0^{\mathrm{b}}$ & $23.36 \pm 10.0^{\mathrm{c}}$ \\
\hline & M. azedarach & Height $(\mathrm{cm})$ & $175.6 \pm 4.10^{\mathrm{a}}$ & $168.3 \pm 3.77^{\mathrm{a}}$ & $147.3 \pm 5.13^{\mathrm{b}}$ & $133.3 \pm 2.09^{b}$ \\
\hline & & Basal diameter $(\mathrm{cm})$ & $31.0 \pm 1.5^{\mathrm{a}}$ & $29.6 \pm 2.0^{\mathrm{a}}$ & $26.8 \pm 0.3^{\mathrm{a}}$ & $20.6 \pm 4.0^{\mathrm{b}}$ \\
\hline & & No. of branches & $8 \pm 3.0^{\mathrm{a}}$ & $8 \pm 3.0^{\mathrm{a}}$ & $8 \pm 3.0^{\mathrm{a}}$ & $8 \pm 3.0^{\mathrm{a}}$ \\
\hline & & No. of leaves & $360 \pm 7.0^{\mathrm{a}}$ & $341 \pm 7.5^{\mathrm{a}}$ & $314 \pm 3.1^{\mathrm{b}}$ & $280 \pm 4.5^{\mathrm{c}}$ \\
\hline & & Relative chlorophyll content & $62.00 \pm 2.0^{\mathrm{a}}$ & $57.75 \pm 3.3^{\mathrm{a}}$ & $47.16 \pm 6.0^{\mathrm{b}}$ & $40.31 \pm 1.2^{\mathrm{b}}$ \\
\hline & & Stomatal conductance $\left(\mathrm{mmol} /\left(\mathrm{m}^{2} \cdot \mathrm{s}\right)\right)$ & $60.70 \pm 3.8^{\mathrm{a}}$ & $58.00 \pm 3.2^{\mathrm{a}}$ & $49.13 \pm 5.0^{\mathrm{b}}$ & $40.73 \pm 2.3^{\mathrm{c}}$ \\
\hline & M. alba & Height $(\mathrm{cm})$ & $158.6 \pm 1.76^{\mathrm{a}}$ & $145.0 \pm 7.00^{\mathrm{a}}$ & $128.0 \pm 3.21^{\mathrm{b}}$ & $115.3 \pm 3.16^{\mathrm{c}}$ \\
\hline & & Basal diameter $(\mathrm{cm})$ & $26.6 \pm 3.0^{\mathrm{a}}$ & $23.1 \pm 3.0^{\mathrm{a}}$ & $23.0 \pm 2.0^{\mathrm{a}}$ & $20.7 \pm 0.0^{\mathrm{b}}$ \\
\hline & & No. of branches & $27 \pm 3.0^{\mathrm{a}}$ & $27 \pm 2.0^{\mathrm{a}}$ & $26 \pm 3.0^{\mathrm{a}}$ & $26 \pm 2.5^{\mathrm{a}}$ \\
\hline & & No. of leaves & $500 \pm 9.1^{\mathrm{a}}$ & $470 \pm 6.9^{\mathrm{a}}$ & $391 \pm 5.7^{b}$ & $360 \pm 6.1^{\mathrm{c}}$ \\
\hline & & Relative chlorophyll content & $48.47 \pm 1.8^{\mathrm{a}}$ & $46.1 \pm 7.5^{\mathrm{a}}$ & $38.16 \pm 3.7^{\mathrm{b}}$ & $32.13 \pm 1.3^{\mathrm{b}}$ \\
\hline & & Stomatal conductance $\left(\mathrm{mmol} /\left(\mathrm{m}^{2} \cdot \mathrm{s}\right)\right)$ & $46.80 \pm 1.6^{\mathrm{a}}$ & $42.23 \pm 1.01^{\mathrm{a}}$ & $30.86 \pm 4.6^{\mathrm{b}}$ & $29.60 \pm 4.0^{\mathrm{b}}$ \\
\hline & R. pseudoacacia & Height $(\mathrm{cm})$ & $146.6 \pm 8.01^{\mathrm{a}}$ & $139.6 \pm 5.77^{\mathrm{a}}$ & $123.6 \pm 3.01^{\mathrm{b}}$ & $106.6 \pm 3.20^{\mathrm{c}}$ \\
\hline & & Basal diameter $(\mathrm{cm})$ & $27.5 \pm 2.0^{\mathrm{a}}$ & $26.1 \pm 2.0^{\mathrm{a}}$ & $25.6 \pm 1.0^{\mathrm{a}}$ & $18.0 \pm 3.1^{\mathrm{b}}$ \\
\hline & & No. of branches & $14 \pm 0.0^{\mathrm{a}}$ & $14 \pm 3.0^{\mathrm{a}}$ & $15 \pm 3.0^{\mathrm{a}}$ & $16 \pm 3.0^{\mathrm{a}}$ \\
\hline & & No. of leaves & $83 \pm 1.3^{\mathrm{a}}$ & $79 \pm 2.1^{\mathrm{a}}$ & $69 \pm 3.0^{\mathrm{b}}$ & $60 \pm 6.0^{\mathrm{c}}$ \\
\hline & & Relative chlorophyll content & $17.57 \pm 2.5^{\mathrm{a}}$ & $16.81 \pm 0.0^{\mathrm{a}}$ & $12.55 \pm 1.3^{\mathrm{b}}$ & $11.12 \pm 5.4^{\mathrm{c}}$ \\
\hline & & Stomatal conductance $\left(\mathrm{mmol} /\left(\mathrm{m}^{2} \cdot \mathrm{s}\right)\right)$ & $34.46 \pm 5.8^{\mathrm{a}}$ & $32.30 \pm 0.0^{\mathrm{a}}$ & $24.46 \pm 4.5^{\mathrm{b}}$ & $22.00 \pm 3.7^{\mathrm{b}}$ \\
\hline
\end{tabular}

Note: The same lowercase letters within a row indicate no significant difference at $P<0.05$ level.

plant height, basal diameter, number of branches, number of leaves, chlorophyll content and stomatal conductance as compared with the other treatments. The use of the subsurface irrigation system may provide an increase in the efficiency of water use. These systems deliver irrigation 
water directly into the soil near the plant roots instead of superficial irrigation (Ayars et al., 1999). The subsurface irrigation system reduces water evaporation due to sun exposure and the slow release of water minimizes the nutrient loss from the rhizosphere through leaching. And it maximizes the usage of water in arid land restoration projects. Plant product quality is often significantly improved by using the subsurface irrigation system (Phene et al., 1987). Therefore, subsurface irrigation is strongly recommended under water scarcity conditions. Elhindi et al. (2016) concluded that the capability of the subsurface drip irrigation to improve growth and yield could be attributed to a low water loss from the soil surface due to vaporization.

The reservoirs with low permeability were more suitable than the reservoirs with high and medium permeability. Theoretically, the difference in water consumption rate may affect the growth indicators of these plants. The low-permeability reservoirs regularly and gradually provided water and nutrients to plants. Some studies have shown that absorption of water and nutrients is greater under continuous low-flux conditions (Segal et al., 2000; Ben-Gal and Dudley, 2003).

\subsection{Percentage of saplings survival}

Studies have shown that water is a factor limiting sapling survival on arid lands. Water deficit can severely affect growth and survival by reduction in the uptake of nutrients and loss of cell turgor (Fitter and Hay, 1987). Although some studies have shown that irrigation can substantially increase sapling survival, few data are available on the physiological responses of tree saplings to different irrigation systems. This study was undertaken with the aim of optimizing irrigation to aid the establishment of tree saplings on arid lands.

The highest percentage of survival was $100 \%$ associated with the subsurface irrigation while the control treatment (surface irrigation) had the lowest survival percentages of $60 \%, 70 \%, 80 \%$ and $100 \%$ for M. alba, M. azedarach, A. altissima and R. pseudoacacia, respectively (Table 7). Saplings can be especially vulnerable to water deficiency due to their lower ability to take up water resources from the soil (Savé et al., 1999; Lloret et al., 2004). The subsurface irrigation system, which involves applying small increments of water at multiple times per day rather than applying a larger amount of water for a longer duration, has been advocated as a procedure to improve surface and near-surface wetting for the better plant establishment. Sterrett et al. (1990) concluded that the establishment of transplants was significantly improved with the subsurface irrigation.

Table 7 Survival percentage of the tree saplings as affected by the irrigation systems

\begin{tabular}{ccc}
\hline Species & Subsurface irrigation (\%) & Surface irrigation (\%) \\
\hline A. altissima & 100 & 80 \\
M. azedarach & 100 & 70 \\
M. alba & 100 & 60 \\
R. pseudoacacia & 100 & 100 \\
\hline
\end{tabular}

\section{$3.4 \boldsymbol{\Psi}_{\mathrm{w}}$}

The aim of measuring $\Psi_{\mathrm{w}}$ is to select the suitable species for restoration projects. It is well known that measurement of $\Psi_{\mathrm{w}}$ is a reliable direct method of determining a plant's water deficiency (Schneider et al., 2006; Endres, 2007), and is indirectly related to drought resistance. Sakcali and Ozturk (2004) used relative water content, $\Psi_{\mathrm{w}}$ and conductance to water vapor of leaf to select suitable drought resistant species for transferring from a healthy site to a degraded site. Results of Table 8 showed that $R$. pseudoacacia, A. altissima, $M$. azedarach and $M$. alba are drought-resistant species in a descending order. Among the studied species, R. pseudoacacia is the most resistant species and it is recommended to revive the arid areas. Minucci et al. (2017) conclude that $R$. pseudoacacia was resistant to increased drought frequency because it employed two strategies, i.e., drought tolerance or drought avoidance, followed by compensation. Symbiotic $\mathrm{N}_{2}$ fixation may play a role in both by supplying nitrogen to leaf tissues for assimilation and by facilitating compensatory growth following drought. $R$. pseudoacacia usually produces a shallow and wide-spreading root system that is excellent for the binding of soil particles but is also 
capable of producing deep roots (5-7 $\mathrm{m}$ deep) and radial root spread is about 1.0-1.5 times tree height (Cutler, 1978).

The drought tolerance of $A$. altissima is high due to its ability to effectively store water in its root system (Hoshovsky, 1988). It is frequently found in areas where few trees can survive. Its roots are also aggressive enough to cause damage to subterranean sewers and pipes (Hu, 1979). Along highways it often forms dense thickets in which few other tree species grow, largely due to the toxins it produces to prevent competition (Hoshovsky, 1988). M. azedarach prefers dry sites, especially in gulches and pastures in Hawaii (Warren et al., 1999). Reviews indicate that $M$. azedarach is drought tolerant in Texas (reviewed by Camilli (2006)), although one flora indicates otherwise (Vines, 1960). In southwestern Alabama, M. azedarach is a species occasionally found on well-drained sites (Gemborys and Hodgkins, 1971). Huang et al. (2013) found that under different degrees of drought, the growth of $M$. alba trees will be inhibited, but the trees can respond to water deficiency by increasing the root absorption surfaces and enhancing their capacity for water retention. The trees demonstrate strong resistance to water deficiency, and furthermore drought resistance can be improved by drought hardening during the seedling stage.

Table 8 Analysis of variance of leaf water potential of the tree saplings as affected by the irrigation systems

\begin{tabular}{|c|c|c|c|c|c|}
\hline Species & Treatment & Mean \pm SE (bar) & Mean square & $F$ & $P$ \\
\hline \multirow{2}{*}{ R. pseudoacacia } & Before irrigation & $-31.33 \pm 7.20$ & \multirow{2}{*}{652.68} & \multirow{2}{*}{24.57} & \multirow{2}{*}{0.01} \\
\hline & After irrigation & $-16.58 \pm 1.11$ & & & \\
\hline \multirow{2}{*}{ A. altissima } & Before irrigation & $-42.00 \pm 10.55$ & \multirow{2}{*}{1788.52} & \multirow{2}{*}{30.69} & \multirow{2}{*}{0.01} \\
\hline & After irrigation & $-17.58 \pm 2.24$ & & & \\
\hline \multirow{2}{*}{ M. azedarach } & Before irrigation & $-45.25 \pm 10.60$ & \multirow{2}{*}{1575.52} & \multirow{2}{*}{19.81} & \multirow{2}{*}{0.01} \\
\hline & After irrigation & $-22.33 \pm 6.83$ & & & \\
\hline \multirow{2}{*}{ M. alba } & Before irrigation & $-50.00 \pm 6.48$ & \multirow{2}{*}{588.00} & \multirow{2}{*}{7.33} & \multirow{2}{*}{0.02} \\
\hline & After irrigation & $-36.00 \pm 0.88$ & & & \\
\hline
\end{tabular}

Note: SE, standard error.

\section{Conclusions}

The problem of water scarcity and the need for restoration of arid lands are going to be serious in many parts of the world. Therefore, effective use of water and efficient irrigation systems are needed. Surface irrigation exposes water to sun radiation especially in extremely hot conditions and should be replaced by innovative subsurface irrigational techniques, which preserve water from loss and evaporation. It is extremely important for a tree sapling to have access to sufficient water resources especially at the early stages of growth in comparison with the later stages when the plant is fully grown and has a well-developed root system. A subsurface water reservoir was used in this research, which is located next to the plant roots and gradually makes water available through its clay walls, ensures the healthy establishment of the plant, and increases the survival chances of the newly planted saplings in arid conditions. Reservoirs with different permeabilities were produced by mixing different materials with the clay to adapt it to the plant's water requirements. The plant responses, namely height, basal diameter, number of leaves, chlorophyll content and stomatal conductance, significantly increased in the subsurface irrigation treatments. Finally, the treatments with low permeability were significantly more successful in supporting the saplings. In addition, $\Psi_{\mathrm{w}}$ is used to evaluate the resistance of each species to water deficiency. Result of the value of $\Psi_{\mathrm{w}}$ confirmed that $R$. pseudoacacia was the most drought-resistant species among the tree species studied. It can be successfully used for the restoration projects. Evidently, the present research may guide future studies on the potential of subsurface water reservoirs and irrigation systems for watering crops, vegetables and fruit trees.

\section{Acknowledgements}

This study was supported by the Isfahan University of Technology, Iran (2018). We especially thank the 
anonymous reviewers and the editor for their careful reading and many insightful comments and suggestions.

\section{References}

Abubaker B M A, Yu S E, Shao G S, et al. 2014. Effect of irrigation levels on the growth, yield and quality of potato. Journal of Agricultural Science, 20(2): 303-309.

Amoud A I. 2010. Subsurface drip irrigation for date palm trees to conserve water. Acta Horticulturae, 882: 103-114.

Ansari H, Naderainfar M, Ramazani H, et al. 2014. Comparison and evaluation of some of growth indices of the dominant species of urban green spaces in the jar subsurface, drip and surface irrigation systems. Iranian Journal of Irrigation and Drainage, 2: 402-412.

Ashrafi S, Gupta A D, Babel M S, et al. 2002. Simulation of infiltration from porous clay pipe in subsurface irrigation. Hydrological Sciences Journal, 47: 253-268.

Ayars J, Phene C, Hutmacher R, et al. 1999. Subsurface drip irrigation of row crops: a review of 15 years of research at the water management research laboratory. Agricultural Water Management, 42(1): 1-27.

Azizi S. Tabari Kochaksarai M. et al. 2015. Responding of the survival and growth of the Populus euphratica Oliv. to the waterlogging-salinity stresses. Desert Ecosystem Engineering Journal, 4: 9-20.

Bainbridge D A. 2001. Buried clay pot irrigation: a little known but very efficient traditional method of irrigation. Agricultural Water Management, 48(2): 79-88.

Bhatt N, Kanzariya B, Motiani A, et al. 2013. An experimental investigation on pitcher irrigation technique on alkaline soil with saline irrigation water. International Journal of Engineering Science and Innovative Technology (IJESIT), 6(2):211-206 .

Bouyoucos G J. 1962. Hydrometer method improved for making particle size analyses of soils. Agronomy Journal, 54: 464-465.

Camilli K. 2006. Chinaberry: a threat to Texas forests-eleventh of the "dirty dozen". In: Texas Forestry, Newsletter of the Texas Forestry Association, 13-14.

Camp C. 1998. Subsurface drip irrigation: a review. Transactions of the ASAE, 41: 1353.

Chang S X, Robison D J. 2003. Nondestructive and rapid estimation of hardwood foliar nitrogen status using the SPAD-502 chlorophyll meter. Forest Ecology Management, 181(3): 331-338.

Cutler D F. 1978. Survey and identification of tree roots. Journal of Arboricultural, 3: 243-246.

Elhindi E, El-Hendawy S, Abdel-Salam E, et al. 2016. Impacts of fertigation via surface and subsurface drip irrigation on growth rate, yield and flower quality of Zinnia elegans. Bragantia, 75(1), 96-107.

El-Shikha D M. 2008. Optimum plant-pan coefficient for surface and subsurface drip irrigated potato grown under Egyptian weather conditions. In: American Society of Agricultural and Biological Engineers 2008 Providence, Rhode Island, June 29-July 2.

Ekren S, Sönmez Ç, Özçakal E, et al. 2012. The effect of different irrigation water levels on yield and quality characteristics of purple basil (Ocimum basilicum L.). Agricultural Water Management, 109: 155-161.

Fitter A H, Hay R K M. 1987. Environmental Physiology of Plants ( $2^{\text {nd }}$ ed). New York: Academic Press, 423.

Gemborys S R, Hodgkins Earl J. 1971. Forests of small stream bottoms in the coastal plain of southwestern Alabama. Journal of Ecology, 52: 70-84.

Grossman R B, Reinsch T G. 2002. Bulk density and linear extensibility. In: Dick W A. Methods of Soil Analysis: Physical Methods. Madison: Soil Science Society of America, 201-228.

Gunston H, Ali M H. 2012. Practices of Irrigation and On-Farm Water Management-Volume 2. Heidelberg: Springer, 155.

Heitzman P G. 1977. "Subsurface infiltration system" for tree irrigation. In: Roadway Development Division, Washington State Department of Transportation, Washington, USA.

Hoshovsky M C. 1988. Element Stewardship Abstract for Ailanthus altissima. Arlington: The Nature Conservancy, 11-88.

$\mathrm{Hu}$ H, Zhang G, Zheng K. 2014. Modeling leaf image, chlorophyll fluorescence, reflectance from SPAD readings. IEEE Journal of Selected Topics in Applied Earth Observations and Remote Sensing, 7(11): 4368-4373.

Hu S Y. 1979. Ailanthus altissima. Arnoldia, 39: 29-50.

Huang X, Liu Y, Li J, et al. 2013. The response of mulberry trees after seedling hardening to summer drought in the hydro-fluctuation belt of Three Gorges Reservoir areas. Environmental Science and Pollution Research, 20: 7103-7111.

Islam T, Sarker H, Alam J. 1990. Water use and yield relationships of irrigated potato. Agricultural Water Management, 18(2): 173-179.

Kirkham M B. 2014. Principles of Soil and Plant Water Relations ( $2^{\text {nd }}$ ed.). Pittsburgh: Academic Press, 598.

Klute A. 1986. Methods of Soil Analysis, Part 1. Physical and Mineralogical Properties (2 ${ }^{\text {nd }}$ ed). Madison: American Society of 
Agronomy and Soil Science Society of America, 1188.

Levidow L, Zaccaria D, Maia R, et al. 2014. Improving water-efficient irrigation: Prospects and difficulties of innovative practices. Agricultural Water Management, 146: 84-94.

Lloret F, Penuelas J, Ogaya R. 2004. Establishment of co-existing Mediterranean tree species under a varying soil moisture regime. Journal of Vegetation Science, 15(2): 237-244.

Moghbeli Moheni Dorodi A, Delbari M, Koohi N. 2014. Investigation of vegetative and reproductive traits of Rosa damascena in different drip and surface irrigation regimes. Iranian Journal of Water and Soil Research, 46 (4): 673-683. (in Arabic)

Minucci J M, Miniat C F, Teskey R O, et al. 2017. Tolerance or avoidance: drought frequency determines the response of an $\mathrm{N}_{2}$-fixing tree. New Phytologist, 215(1): 434-442.

Naik B, Panda R, Nayak S, et al. 2008. Hydraulics and salinity profile of pitcher irrigation in saline water condition. Agricultural Water Management, 95(10): 1129-1134.

Nielsen D C, Nelson N O. 1998. Black bean sensitivity to water stress at various growth stages. Crop Science, 38(2): $422-427$.

Pagola M, Ortiz R, Irigoyen I, et al. 2009. New method to assess barley nitrogen nutrition status based on image colour analysis: Comparison with SPAD-502. Computers and Electronics in Agriculture, 65(2): 213-218.

Pask A J D, Pietragalla J, Mullan D M. et al. 2012. Physiological Breeding II: A Field Guide to Wheat Phenotyping. Mexico: Cimmyt, 132.

Phene C J, Davis K R, Hutmacher R B, et al. 1987. Advantages of subsurface irrigation for processing tomatoes. Acta Horticulturae, 200: 101-114.

Postel S L. 2000. Entering an era of water scarcity: the challenges ahead. Ecological Applications, 10(4): 941-948.

Raij B V. 1966. Determination of calcium and magnesium by EDTA in extracts from soils. Bragantia, 25: 317-326.

Rao K V R, Gangwar S, Aherwar P, et al. 2019. Growth, yield, economics and water use efficiency of onion (Allium cepa L.) under different micro irrigation systems. Journal of Pharmacognosy and Phytochemistry, 8(3): 3866-3869.

Sanches A C, Gomes E P, Azevedo E P G. 2017. Canola yield under different irrigation frequencies and nitrogen levels in the Brazilian Cerrado. Ciência e Agrotecnologia, 41(4): 367-377.

Savé R, Castell C, Terradas J. 1999. Gas exchange and water relations. In: Rodà F, Retana J, Gracia C A, et al. Ecology of Mediterranean Evergreen Oak Forests. Berlin: Springer-Verlag, 135-147.

Sims D A, Gamon J A. 2002. Relationships between leaf pigment content and spectral reflectance across a wide range of species, leaf structures and developmental stages. Remote Sensing of Environment, 81(2-3): 337-354.

Slavich P, Petterson G. 1993. Estimating the electrical conductivity of saturated paste extracts from 1:5 soil, water suspensions and texture. Soil Research, 31(1): 73-81.

Tallant B, Pelkki M. 2004. A comparison of four forest inventory tools in southeast Arkansas. In: Proceedings of the Southern Forest Economics Workshop, 23-34.

Thompson T L, Doerge T A. 1996. Nitrogen and water interactions in subsurface trickle-irrigated leaf lettuce II. Agronomic, economic, and environmental outcomes. Soil Science Society of America Journal, 60(1): 168-173.

Vines Robert A. 1960. Trees, Shrubs, and Woody Vines of the Southwest. Austin: University of Texas Press, 1104.

Warren L W, Derral R Herbst, Sohmer S H. 1999. Manual of the Flowering Plants of Hawai'i. Revised Edition: Volume 1. Honolulu: Bishop Museum Press, 988.

Water U N. 2007. Coping with water scarcity: challenge of the twenty-first century. In: World Water Day, United Nations, Rome, Italy, 1-29.

Zaccaria D, Carrillo-Cobo M T, Montazar A, et al. 2017. Assessing the viability of sub-surface drip irrigation for resource-efficient alfalfa production in Central and Southern California. Water, 9: 837.

Zhang J. 1996. Interactive effects of soil nutrients, moisture and sand burial on the development, physiology, biomass and fitness of Cakile edentula. Annals of Botany, 78(5): 591-598.

Zhang J, Niu W, Zhang L L, et al. 2012. Experimental study on characters of wetted soil in moist-tube irrigation. Science of Soil and Water Conservation, 10: 32-38. 